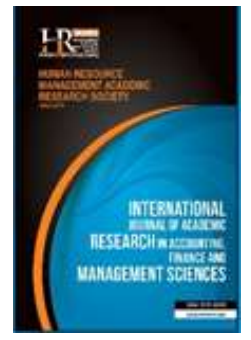

International Journal of Academic Research in Accounting, Finance and Management Sciences

Vol. 9, No.3, July 2019, pp. 128-139

E-ISSN: 2225-8329, P-ISSN: 2308-0337

(c) 2019 HRMARS

www.hrmars.com

To cite this article: Pahlevi, C., Ruslan, A. (2019). Effect of Market Structure and Financial Characteristics on Bank Performance in Indonesia, International Journal of Academic Research in Accounting, Finance and Management Sciences 9 (3): 128-139

http://dx.doi.org/10.6007/IJARAFMS/v9-i3/6347 (DOI: 10.6007/IJARAFMS/v9-i3/6347)

\title{
Effect of Market Structure and Financial Characteristics on Bank Performance in Indonesia
}

\author{
Cepi Pahlevi ${ }^{1}$, Andi Ruslan ${ }^{2}$ \\ ${ }^{1}$ Department of Management, Faculty of Economics and Business, Hasanuddin University Makassar, Indonesia, \\ ${ }^{1}$ E-mail: cepipahlevi.999@gmail.com (Corresponding author) \\ ${ }^{2}$ Islamic Banking Study Program, Faculty of Economics and Business Islam, Institute for Islam Studies (IAIN) Bone, \\ Watampone, Indonesia, ${ }^{2}$ E-mail: oland3aa@gmail.com
}

\begin{abstract}
Purpose of this study is to obtain empirical evidence of the influence of market structure as measured by the Herfindahl-Hirschman Index (HHI) and Lerner Index, financial characteristics measured by capital, bank size on bank performance. The research sample is a Conventional Commercial Bank that has a minimum core capital of Rp. 5,000,000,000,000 and publishes financial statements in full during 2011-2018. Data analysis techniques in this study are panel data regression. The results showed that the Herfindahl-Hirschman Index proved to have a negative and significant influence on bank performance. The higher the HerfindahlHirschman Index shows the market structure that leads to a monopoly structure so that in general it will have an impact on decreasing bank performance. The Lerner Index proved to have a positive and significant influence on bank performance. It shows that when the monopoly power of individual banks increases, it will have an impact on the mastery of sources and assets owned by banks, which in turn will have an impact on increasing bank performance. Bank size and Capital proved to have a positive and significant influence on Bank performance.

Key words Herfindahl-Hirschman Index, Lerner Index, Bank Size, Capital, Bank Performance

Received: 17 July $2019 \quad$ (c) The Authors 2019

Revised: 28 Aug 2019 Published by Human Resource Management Academic Research Society (www.hrmars.com)

Accepted: 30 Aug 2019 This article is published under the Creative Commons Attribution (CC BY 4.0) license. Anyone may reproduce, distribute, translate and create derivative works of this article (for both commercial and non-commercial purposes), subject to full attribution to the original publication and authors. The full terms of this license may be seen at: http://creativecommons.org/licences/by/4.0/legalcode
\end{abstract}

\section{Introduction}

Based on the Indonesian Financial System Statistics (SSKI) the banking industry in Indonesia still dominates the market share of $77.71 \%$ in December 2018 (Bank Indonesia, 2019) with an industry profit of Rp. 150 Trillion with a Return on Assets (ROA) ratio of $2.55 \%$. This shows that the banking industry has high profitability and has an important role in the Indonesian economy (Keuangan, 2018) Therefore, the banking sector must be able to operate healthily and have good performance to encourage sustainable and more equitable economic growth through easy, safe and affordable financing.

One indicator to assess the performance of a bank is to look at the level of profitability. The main purpose of bank operations is to achieve maximum levels of profitability (Vernanda and Widyarti, 2016). Profitability is the ability of banks to generate or earn profits effectively and efficiently. If you want to achieve an efficient financial system, financial institutions must record an increase in profitability; increase the volume of funds flowing from savers to borrowers, and better-quality services for customers. The 
importance of bank profitability in the economy can be assessed at the micro and macro level (Menicucci and Paolucci, 2016).

Many factors can affect bank performance; these factors consist of internal factors and external factors beyond the control of the company or bank. external factors consist of the level of competition or market structure and economic conditions), internal factors can comprise the financial characteristics and activities of the bank. The condition of competition can be seen through the level of competition in an industry. The level of competition can be measured using structural and non-structural approaches. According to the first approach, there is a direct relationship between market structure, company behavior, and industry performance. This approach is based on the traditional approach of Structure ConductPerformance (Mulyaningsih and Daly, 2012). The second non-structural approach, as explained by Shaffer (2014), competitive conditions such as efficient prices can be achieved in non-concentrated and concentrated market conditions so that the relationship between market structure and performance is not linear. One study has been conducted to determine the level of banking competition in Indonesia, including Claessens and Leaven (2003) who estimated market structure in 50 countries including Indonesia using a non-structural approach with the Panzar-Rosse method in the period 1994--2001. Another study from Mulyaningsih and Daly (2012) related to the structure of the banking market in Indonesia in 2001-2009. From the study, finding the structure of the Indonesian banking industry belonged to the category of monopolistic competition. Another study from Jumono et al. (2016) examined the banking market structure in Indonesia in 2001-2014 with a structural approach using the Concentration Ratio and Herfindahl-Hirschman Index (HHI) which found that the level of banking competition in Indonesia was included in the loose oligopoly or monopolistic competition category.

Another factor that influences bank performance is the bank's internal factors, namely the characteristics of the bank. The characteristics of banks can consist of bank size, bank capital. Barney, Wright, and Ketchen (2001); Priem and Butler (2001) the performance and excellence of the company is very much determined by the characteristics of the resources and capabilities possessed by the company, one of which is an organization that is characteristic of organizations that can build incentives, structures and organizational culture that are aligned so as to provide support for people who are in it to utilize existing resources effectively and efficiently. Research related to this done by (Muazaroh et al., 2012) found that bank size, capital, type or structure of bank ownership have a positive effect on bank performance. Research conducted by Yusniar (2011) also found that bank characteristics such as bank size and capital affected the bank's performance.

According to Athanasoglou et al., (2005) an economy that has a bank with better profitability will be able to withstand negative shocks and contribute to the creation of state financial sector stability. Based on this statement, developing countries like Indonesia need to monitor the effectiveness of banks by paying attention to the level of banking performance.

This research measures performance with the Return on Assets (ROA) ratio. According to (Margaretha, 2006), ROA has a very important role in the financial performance of a company or banking. The good and bad condition of a company can be seen quickly through ROA position, if the value of ROA is large enough, the greater the level of profit achieved by the bank and the more the position of the bank in terms of asset use. According to the Bank Indonesia Circular Letter in 2004, good ROA is worth more than $1.25 \%$

Based on the background above, the formulation of the problem in this study is whether the market structure measured by the Herfindahl-Hirschman Index (HHI) and Index Lerner and financial characteristics measured by capital, bank size affect the performance of the bank. The purpose of this study is to obtain empirical evidence of the influence of market structure and financial characteristics on bank performance.

\section{Literature review}

\subsection{The Structure of Conduct Performance Theory}

Paradigm The Structure Conduct Performance (SCP) is a paradigm in industrial economics that is used to link market structure elements to the behavior and performance of a structured industry, referring to market structures that are usually defined by market concentration ratios. The market concentration ratio is a ratio that measures the distribution of market share in an industry. Conduct is a company's behavior in 
the industry (Naylah, 2010). This behavior is competitive or collusive, such as pricing, advertising, production, and predation. While Performance or performance is a measure of social efficiency which is usually defined by the ratio of market power (where the greater the market power the lower the social efficiency). Another measure of performance is company profit or profitability. The SCP paradigm is based on several hypotheses, namely: 1) Structure influences behavior. The lower the market concentration, the higher the level of competition in the market; 2) Behavior affects performance. The higher the level of competition or competition, the lower the market power or the lower the company profits obtained; and 3) Structure affects performance. The lower the market concentration, the lower the level of collusion that occurs, or the higher the level of competition, the lower the market power. The third result of the hypothesis above shows the market structure affects the performance of companies in an industry.

There are three thoughts in the Structure Conduct Performance (SCP) paradigm to explain the relationship between market structure and company performance, especially explaining concentration and market share as variables of market structure, namely:

1. The traditional hypothesis which assumes that concentration is a proxy of market power where the market concentration increases, the cost of collusion is low, so companies in the industry will get supernormal profits. Therefore, the market concentration will positively influence profitability as a proxy for performance.

2. Differentiation hypothesis that considers that market share is the result of product differentiation where companies that make product differentiation can increase their market share and then companies can set a higher price level which means they will get high profits as well. Thus there will be a positive relationship between profitability as a proxy for performance and market share as a proxy for market structure.

3. Efficient structure hypothesis that assumes that market share and concentration is not a proxy of market power but is a proxy of company efficiency, so that high concentrations are not identical to collusion. Where more efficient companies will get a large market share so that the industry will also tend to be more concentrated.

Based on this thinking, the relationship between concentration and profitability is a relationship that does not occur, considering that concentration is only an aggregate of market share resulting from behavioral efficiency, and more efficient companies will be able to earn greater profits. (Suhel, 2015).

The basis of the SCP approach was built by Manson (1939). He concluded that fewer companies in the market would push markets that were not competitive, reflected in higher prices and fewer items, such as monopolistic market conditions. Furthermore, a concentrated market will produce lower competitive performance where the price to cost ratio will be greater, and at the expense of consumer welfare. Smaller companies can also encourage them to cooperate with their rivals. This collusion which will increase prices is far greater than marginal costs (Yeyati and Micco, 2007).

\subsection{The Effect of Market Structure (Herfindahl-Hirschman Index) on the Performance}

Herfindahl-Hirschman Index ( $\mathrm{HHI}$ ) is a measure to assess market concentration and the relative size of each company to its industry (Soelistianingsih and Oktaviani, 2013). The advantages of the HHI analysis compared to CR4 are first, the Herfindahl Index ( $\mathrm{HHI}$ ) reflects the distribution of market share from the top four companies and the composition of the market outside the four companies. Second, HHI gives greater weight proportionally to market share for larger companies. This reflects a more dominant role for larger companies in competing (Jumono et al., 2016). HHI is also a measure of monopoly power in an industry as a whole which is the sum of the second rank of market shares of all companies engaged in the industrial sector. The higher the Herfindahl-Hirschman Index shows the higher monopoly power of an industry which indicates the low competition in an industry.

(Petria et al., 2015) examined the determinants of profitability performance of EU 27 banking systems in 2004-2011. The results of his research found that the market structure as measured by the Herfindahl-Hirschman Index was one of the determinants of bank profitability. The better market structure marked by a decline in the value of the Herfindahl-Hirschman Index will have an impact on increasing bank profitability. Different results were obtained (Djalilov and Piesse, 2016; Tan, 2016) which found that the 
level of competition measured by market structure using the Herfindahl-Hirschman Index did not significantly influence the profitability of banks.

Hypothesis 1: Herfindahl-Hirschman Index had a negative influence on Bank Performance

\subsection{The Effect of Market Structure (Lerner Index) on the Performance}

Market structure can also be measured using the Lerner Index (L), this index measures the level of monopoly power held by a company. The unit is $L$ which is the ratio between price difference $(P)$ and marginal cost (MC) to price, or bias is also divided by the absolute number/value of the demand price elasticity (e). The value of $L$ can range from zero (for perfect competitive companies) to one (for monopoly companies) (Salvatore, 2006).

In contrast to the $\mathrm{HHI}$ index that measures monopoly power in an industry as a whole which is the sum of two powers over market shares of all companies engaged in the industrial sector. Lerner index (LI) measures the level of monopoly power held by a company. The higher the Lerner index (LI) shows the higher the monopoly strength of a company.

The Lerner index does not measure market structure by referring directly to the concentration level of the industry but building a model that refers to the level of profit, which is a comparison between the prevailing price differences and the total cost of output prices in the industry. The Lerner index is used as a proxy for market power. The high Lerner index shows a strong level of monopoly in the banking market, while in highly competitive markets this sector has less capacity to set high margins which result in a low Lerner index. Research Refers to the Lerner index formulated by (Hawtrey and Liang, 2008).

(Martins et al., 2019) examining the effect of bank characteristics, the industrial structure measured by the Lerner Index and macroeconomic factors on profitability 108 real estate banks from the US, UK, and Germany during the period 2000 to 2014. The results of his research showed credit risk, liquidity, operational efficiency, Lerner Index, GDP interest rates had a significant impact on bank profitability. The Lerner Index measures the monopoly power of a bank so that the greater the value of the Lerner Index or near one indicates the greater the monopoly power of a bank in the industry.

Different results were obtained (Tan, 2016) which found that the level of competition measured by market structure using the Herfindahl-Hirschman Index and Lerner Index did not have a significant effect on the profitability of banks

Hypothesis 2: Lerner Index had a positive influence on Bank Performance

\subsection{Bank Size Influence on Bank Performance (ROA)}

The size variable in this study uses a proxy of the total assets, more precisely the natural logarithm (In) of total assets. This is because the amount of the total assets of each bank is different and has a far different. Banks with large assets are indeed able to generate large profits if they are balanced with good operational activities. One of the banking operational activities is to provide credit to the community. Large banks generally channel large loans as well. Credit distribution is a productive asset that produces large profits for the bank.

In general, large companies that have large total assets can generate large profits. Larger banks measure assets more favorably than banks with small asset sizes, because larger bank sizes have a higher level of efficiency (Kosmidou and Zopounidis, 2008). With large assets owned by banks, banks can have more productive assets than banks with smaller assets. The results of research (Menicucci and Paolucci, 2016) find that bank size is one of the determinants of the level of profitability of banks in Europe. This is in line with the research (Adelopo et al., 2018), which found that the bank size has a positive effect on ROA.

Hypothesis 3: Bank size has a positive influence on Bank Performance

\subsection{The Effect of Capital on Bank Performance (ROA)}

Variable capital indicates the amount of bank capacity (assets and capital) in carrying out operational activities including credit activities. The proxy used is the Capital Adequacy Ratio (CAR). CAR is a ratio that shows how far all risk-bearing bank assets (credit, participation, securities, bills on other banks) are also financed from the bank's capital funds in addition to obtaining funds from sources outside the bank, such as funds from the public, loans and others (Dendawijaya, 2003). From this understanding means that the 
bank's capital is used to finance assets that contain risks. The higher the capital owned by the bank, the easier it will be for banks to finance assets that contain risk.

CAR is an indicator of a bank's ability to cover a decrease in its assets as a result of bank losses caused by assets at risk, one of which is non-performing loans (NPLS). These risky assets tend to limit the amount of capital available in profit-generating activities. The higher the CAR, the stronger the bank's ability to bear risky earning assets, in this case, NPL, so that it can make bank profitability increase (Vernanda and Widyarti, 2016).

CAR ratio is used as a benchmark for a bank's ability to cover losses caused by risky assets. CAR has a relationship with profitability because CAR is a ratio to calculate how much bank capital is sufficient to support its needs. The greater the CAR indicates the ability of banks to obtain good profits. So CAR has a positive effect on earnings and can increase ROA (Vernanda and Widyarti, 2016) the results of the research (Menicucci and Paolucci, 2016) found that capital ratio is one determinant of the level of profitability of banks in Europe. This is in line with the research (Ambarawati and Abundanti, 2018) which found that Capital has a positive and significant effect on ROA.

\section{Hypothesis 4: Capital has a positive influence on the Bank Performance}

\subsection{Conceptual Framework}

The relationship between variables in this study is built on the theory of Structure Conduct Performance. This research, besides being based on the main theory, also refers to previous studies and rationalization to be able to form a model of theoretical thinking. This research places the DPK market share that connects the promotion costs and bank profitability.

Theory of Structure Conduct Performance (SCP) believes that market structure will affect the performance of an industry. This flow is based on the assumption that the market structure will influence the behavior of the company which will ultimately affect the performance of the company and industry in the aggregate as expressed by Gilbert, 1984. From the perspective of business competition, concentrated market structures tend to potentially lead to various business competition behaviors unhealthy ones to maximize profit. The company can maximize profit $(P>M C)$ because of market power, something that is common for companies with a dominant market position (dominant position). According to Burgess, 1988 (Kv \& Deb, 2008) to analyze the banking industry, variables that are relevant to the banking industry are needed which have characteristics that are different from the industry in general. So that Burgess developed what was stated by Michael R. Baye, namely that the relationship between Structure-ConductPerformance is strongly influenced by the basic conditions of each company. This research was conducted to see the effect of market structure and financial characteristic on bank performance.

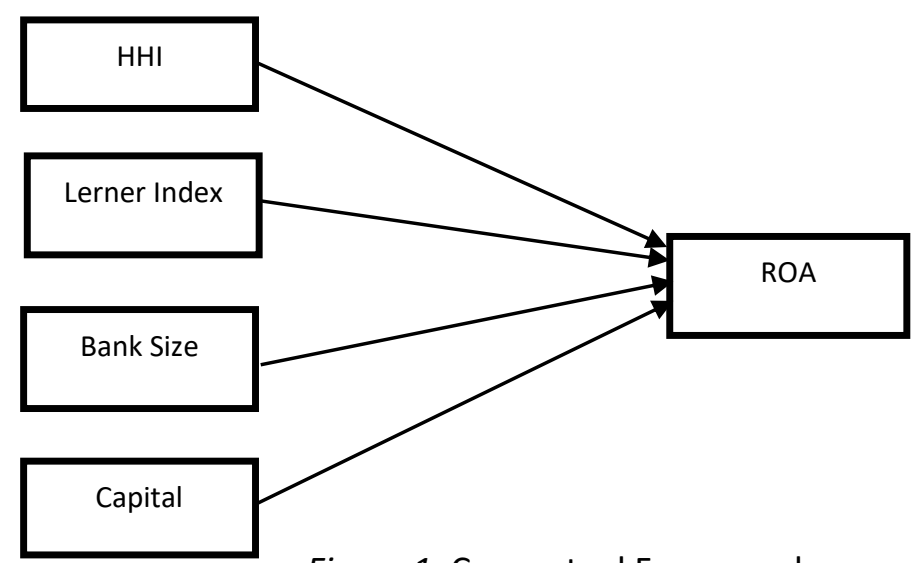

Figure 1. Conceptual Framework 


\section{Methodology of research}

\subsection{Population and Sample}

The population is the total number of groups of individuals or the overall object of research. The population in this study is all banks operating in Indonesia. The sample is part of the population that will be studied and is considered capable of representing the population.

The sampling technique in this study used a purposive sampling technique, which is sampling with certain considerations and criteria by the objectives of the study. The bank that will be used as the research sample is a Conventional Commercial Bank that has a minimum core capital of Rp. 5,000,000,000,000 and publish financial statements in full during 2011-2018. Based on the sampling criteria above, the banks that meet the requirements for use as samples in this study are 25 banks from 2011-2018.

\subsection{Types and Sources of Data}

The types of data used in this study are documentary data in the form of financial statements of 25 banks that have a minimum core capital of Rp. 5,000,000,000,000 and publish financial statements in full during 2011-2018. While the data sources used in this study are secondary data in the form of figures in the annual financial statements obtained from the Financial Services Authority (OJK), Bank Indonesia (BI) or from each bank.

\subsection{Operational Definition of Variables Operational}

definition of the variable aims to explain the meaning of the variable being studied, while the operational definition of the research variable is described in table 2 as follows:

Table 1. Operational Definition of Variable

\begin{tabular}{|c|c|c|c|}
\hline No. & Variable & Definition & Measurement \\
\hline 1 & $\begin{array}{l}\text { Market Structure/ } \\
\text { Herfindahl- } \\
\text { Hirschman Index } \\
\text { (X1) }\end{array}$ & $\begin{array}{l}\text { the measure of monopoly } \\
\text { power in an industry as a whole } \\
\text { which is the sum of two powers } \\
\text { of market shares of all } \\
\text { companies }\end{array}$ & $\begin{array}{l}H H I=\sum_{i=1}^{n} S i^{2} \\
\mathrm{~s}=\text { share of individual bank; } \mathrm{n}=\text { Total banks } \\
\log \mathrm{HHI}\end{array}$ \\
\hline 2 & $\begin{array}{l}\text { Market Structure/ } \\
\text { Lerner index (X2) }\end{array}$ & $\begin{array}{llr}\text { measure } & \text { that shows } & \text { the } \\
\text { monopoly power of an } \\
\text { individual company in an } \\
\text { industry }\end{array}$ & $\begin{array}{l}\text { Lerner Index }=\frac{T R-T C}{T R} \\
\text { Where: } \\
\text { TR = Total Revenue } \\
\mathrm{TC}=\text { Total Cost }\end{array}$ \\
\hline 3 & Bank Size (X3) & $\begin{array}{l}\text { Number of assets owned by } \\
\text { banks }\end{array}$ & Log Total Asset \\
\hline 4 & $\begin{array}{l}\text { Capital Adequacy } \\
\text { Ratio (CAR) (X4) }\end{array}$ & $\begin{array}{l}\text { Ratio for measuring bank capital } \\
\text { adequacy by BI standards Bank } \\
\text { Capital }\end{array}$ & $\frac{\text { Bank Capital }}{\text { ATMR }}$ \\
\hline 5 & Return on Asset (Y) & $\begin{array}{l}\text { The ratio used to measure the } \\
\text { profitability of a bank }\end{array}$ & $\mathrm{ROA}=\frac{\text { Earning Before Tax }}{\text { Total Asset }} \times 100 \%$ \\
\hline
\end{tabular}

Source: Previous Research

\subsection{Data Analysis Techniques}

By referring to the conceptual framework that has been stated previously, then the method chosen for data analysis in this study is Panel Data Regression with the help of EViews software.

\section{Results and discussions}

This study used a sample of 25 banks in 2011-2018 to form 200 data. The following descriptive statistics of each variable of the study: 
Table 2. Statistics Descriptive Research Variables

\begin{tabular}{|l|c|c|c|c|c|}
\hline & $\mathrm{X} 1$ & $\mathrm{X} 2$ & $\mathrm{X} 3$ & $\mathrm{X} 4$ & $\mathrm{Y}$ \\
\hline Mean & 3.002500 & 0.216550 & 7.926650 & 18.56040 & 2.369000 \\
\hline Median & 3.000000 & 0.200000 & 7.855000 & 17.56000 & 2.230000 \\
\hline Maximum & 3.020000 & 0.530000 & 9.030000 & 43.77000 & 5.580000 \\
\hline Minimum & 2.990000 & 0.010000 & 6.380000 & 10.25000 & 0.090000 \\
\hline Std. Dev. & 0.012020 & 0.104003 & 0.481728 & 4.812590 & 1.155862 \\
\hline Observations & 200 & 200 & 200 & 200 & 200 \\
\hline
\end{tabular}

Source: Output Eviews

Based on Table 2 can be described as the variables used in the study as follows:

1. Variable Herfindahl-Hirschman Index (X1) after being converted into Logs during the 2010-2017 observation period the minimum is 2.99 and the maximum value is 3.02 . This means that from the 200 observation data Herfindahl-Hirschman lowest value index is 2.99 percent and the highest value is 3.02 percent. The average Herfindahl-Hirschman Index is 3.00 percent with a standard deviation of 0.012 . The standard deviation value is smaller than the average value that indicates the Herfindahl-Hirschman Index variable is normally distributed.

2. The variable Lerner Index (X2) during the 2010-2017 observation period the minimum value is 0.01 and the maximum value is 0.53 . This means that from the 200 observational data the lowest value Lerner Index is 0.01 percent and the highest value is 0.53 percent. The average Lerner Index Index is 0.21 percent with a standard deviation of 0.10 . The standard deviation value is smaller than the average value that indicates the Lerner Index variable is normally distributed.

3. Variable Bank Size (X3) after being converted into Log during the 2010-2017 observation period the minimum value is 6.38 and the maximum value is 9.03 . This means that from the 200 observation data the Bank Size the lowest value is 6.38 percent and the highest value is 9.03 percent. The average Bank Size is 7.92 percent with a standard deviation of 0.48 . The standard deviation value is smaller than the average value that indicates a normally distributed Bank Size variable.

4. Capital variable (X4) during the 2010-2017 observation period the minimum value is 10.25 and the maximum value is 43.77 . This means that from the 200 observation data the lowest capital value is 10.25 percent and the highest value is 43.77 percent. The average capital is 18.56 percent with a standard deviation of 4.81 . The standard deviation value is smaller than the average value that indicates the variable capital is normally distributed.

5. Performance variables measured by ROA $(Y)$ during the $2010-2017$ observation period the minimum value is 0.09 and the maximum value is 5.58 . This means that from the 200 observational data the lowest performance value is 0.09 percent and the highest value is 43.77 percent. The average performance is 2.36 percent with a standard deviation of 1.15 . The standard deviation value is smaller than the average value that indicates the performance variable is normally distributed.

\subsection{Classical Assumption}

Test Model testing of classical assumptions applied to structural equations in this study includes multicollinearity tests and normality tests.

\section{Multicollinearity Test}

The Multicollinearity test aims to test whether the regression model found a high or perfect correlation between independent variables. The following are the results of testing to detect multicollinearity by using a correlation matrix in the program Eviews.

Table 3. Multicollinearity Test

\begin{tabular}{|c|c|c|c|c|}
\hline & $\mathrm{X} 1$ & $\mathrm{X} 2$ & $\mathrm{X} 3$ & $\mathrm{X} 4$ \\
\hline $\mathrm{X} 1$ & 1.000000 & -0.138182 & 0.222499 & 0.222190 \\
\hline $\mathrm{X} 2$ & -0.138182 & 1.000000 & 0.234549 & 0.111619 \\
\hline $\mathrm{X} 3$ & 0.222499 & 0.234549 & 1.000000 & -0.251414 \\
\hline X4 & 0.222190 & 0.111619 & -0.251414 & 1.000000 \\
\hline
\end{tabular}

Source: Output Eviews 
Based on the results of the correlation matrix output above the correlation between $\mathrm{X} 1, \mathrm{X} 2, \mathrm{X} 3, \mathrm{X} 4$, it shows that there is no correlation between independent variables which is high above 0.80 . So, it can be concluded that there is no multicollinearity between independent variables.

\section{Normality Test}

Normality test aims to test whether, in the regression model, the disturbing or residual variables have a normal distribution.

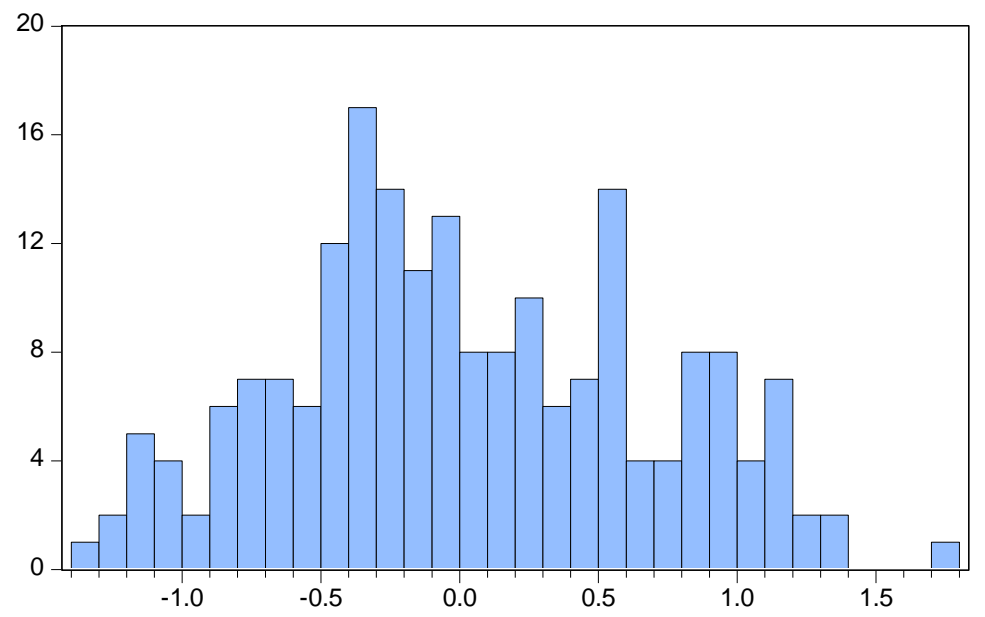

\begin{tabular}{lc} 
Series: Standardized Residuals \\
Sample 2010 2017 \\
Observations 200 \\
Mean & 0.025507 \\
Median & -0.057149 \\
Maximum & 1.792107 \\
Minimum & -1.366658 \\
Std. Dev. & 0.647264 \\
Skewness & 0.167875 \\
Kurtosis & 2.397750 \\
& \\
Jarque-Bera & 3.961947 \\
Probability & 0.137935 \\
\hline
\end{tabular}

Figure 2. Normality Test

Based on the results of testing the classical assumptions, the probability value of Jarque-Bera is equal to 0.1379 . Thus the probability value of Jarque-Bera is greater than alpha 0.05 , so the assumption of normality is fulfilled.

\subsection{Goodness of Fit Model}

The coefficient of determination $\left(R^{2}\right)$ determines the feasibility of the model of a study. The coefficient of determination $\left(R^{2}\right)$ indicates the accuracy or goodness of fit of the model used. The greater the value of the coefficient of determination (R2) or the value is close to one (1), the better the model will be in explaining the effect of independent variables (exogenous) on the dependent variable (endogenous).

Valid Model because the Prob (F-statistic) <prob a $=0.05$, namely: $0.000<0.05$. The model is quite good because the predictor variable (exogenous) in the model contributes 0.57 percent in influencing the response variable (endogenous), the remaining 0.43 percent is influenced by other factors outside the model.

\subsection{Results of Panel Data Regression Analysis}

Table 4. Results of Data Panel Regression

\begin{tabular}{|l|c|c|c|c|c|c|}
\hline No. & Variable & Regression Coefficient & Standard Error & t-Statistik & Prob. & Remarks \\
\hline 1 & $\mathrm{C}$ & 68.15926 & 14.63155 & 4.658375 & 0.0000 & Significant \\
\hline 2 & $\mathrm{X} 1 \rightarrow \mathrm{Y}$ & -24.57509 & 4.999326 & -4.915681 & 0.0000 & Significant \\
\hline 3 & $\mathrm{X} 2 \rightarrow \mathrm{Y}$ & 6.180294 & 0.563043 & 10.97660 & 0.0000 & Significant \\
\hline 4 & $\mathrm{X} 3 \rightarrow \mathrm{Y}$ & 0.686085 & 0.128759 & 5.328451 & 0.0000 & Significant \\
\hline 5 & $\mathrm{X} 4 \rightarrow \mathrm{Y}$ & 0.065718 & 0.012528 & 5.245532 & 0.0000 & Significant \\
\hline
\end{tabular}

Source: Data Processed 2019

Based on analysis data, the estimation of the research equation is as follows:

$Y=68.15-24.57 X_{1}+6.18 X_{2}+0.68 X_{3}+0.06 X_{4}$ 
a. Constanta of 68.15 states that if the value of the exogenous variable is considered zero $(X 1=0, X 2$ $=0, X 3=0, X 4=0$ ) or the value of $X 1, X 2, X 3, X 4$ remains, then the performance value that is proxyed with $\mathrm{ROA}$ is 68.15 .

b. Regression variable regression coefficient or Herfindahl-Hirschman Index (X1) of -24.57 means that if the interest rate variable increase of 1 percent will reduce the value of performance ROA by 24.57 percent.

c. Regression coefficient variable level competition or Lerner Index (X2) of 6.18 means that if the increase in the value of the Lerner Index variable by 1 percent will increase the value of performance ROA of 6.18 percent.

d. The regression variable or Bank Size (X3) coefficient of 0.68 means that if the increase in the Bank Size variable value by 1 percent will increase the value of the performance ROA by 0.68 percent.

e. The competition level regression coefficient or Capital (X3) of 0.06 means that if the increase in the Capital variable value by 1 percent will increase the value of performance ROA by 0.06 percent.

\subsection{Hypothesis Testing}

Hypothesis testing is done by comparing the $p$-value with a significance level (alpha) of 0.05 . If $p$ value <alpha 0.05 then $\mathrm{H}_{0}$ is rejected and $\mathrm{H}_{1}$ is accepted. Conversely, if p-value> alpha 0.05 , then $\mathrm{HO}$ is accepted and $\mathrm{H} 1$ is rejected. The results of hypothesis testing in this study are:

\section{Hypothesis Testing 1}

Based on the results of the regression analysis in table 4 above, the coefficient value of the influence of the level of competition or Herfindahl-Hirschman Index $\left(\mathrm{X}_{1}\right)$ on the bank performance $(\mathrm{Y})$ is -24.57 with a $p$-value of $0.00>$ alpha 0.05 . This shows that the level of competition as measured by the HerfindahlHirschman Index has a negative and significant effect on performance. Thus the $\mathrm{H} 1$ hypothesis states that the level of competition as measured by the Herfindahl-Hirschman Index has a negative and significant effect on accepted bank performance. This is relevant to research (Petria et al., 2015) which examined the determinants of profitability performance of EU 27 banking systems in 2004-2011. The results of his research found that the market structure as measured by the Herfindahl-Hirschman Index was one of the determinants of bank profitability. The better market structure marked by a decline in the value of the Herfindahl-Hirschman Index will have an impact on increasing bank profitability. However, different results were obtained (Djalilov and Piesse, 2016; Tan, 2016) which found that the level of competition measured by market structure using the Herfindahl-Hirschman Index did not significantly influence the profitability.

Herfindahl-Hirschman Index, which showed an increase in banking concentration levels. The trend of increasing levels of banking concentration shows increasing market power. As a result, banks can be monopolistic in theory, indicated by the ability of banks to set prices higher than marginal costs. When there are one or several banks that carry out monopolistic practices, as a result, the competition decreases. The market is controlled by banks that have high market power (Hafidz and Astuti, 2013). This will have an impact on the decline in bank performance which is generally in the industry.

\section{Hypothesis Testing 2}

Based on the results of the regression analysis in table 6 above, the coefficient value of the influence of the level of competition or Lerner Index (X2) on the bank performance $(\mathrm{Y})$ is 6.18 with a $\mathrm{p}$-value of $0.00>$ alpha 0.05 . This shows that the level of competition measured by the Lerner Index has a positive and significant influence on performance. Thus Hypothesis $\mathrm{H} 2$ states that the level of competition measured by the Lerner Index has a positive and significant effect on accepted bank performance. The results of the study support research (Martins et al., 2019) which shows credit risk, liquidity, operational efficiency, index Lerner, GDP interest rates have a significant impact on bank profitability. The Lerner Index measures the monopoly power of a bank so that the greater the value of the Lerner Index or close to one indicates the greater the monopoly power of a bank in the industry. The results of this study indicate that the higher the Lerner Index indicates that the level of monopoly power of individual banks increases which shows an increase in the mastery of sources and assets owned by banks, they will have an impact on increasing bank performance as measured by profitability. 


\section{Hypothesis Testing 3}

Based on the results of the regression analysis in table 6 above, the coefficient of influence of Bank Size $(X 3)$ on the bank performance $(Y)$ is 0.68 with a $p$-value of $0.00>$ alpha 0.05 . This shows that Bank Size has a positive and significant influence on performance. Thus the $\mathrm{H} 3$ hypothesis which states that Bank Size has a positive and significant influence on bank performance is accepted. Capital Adequacy Ratio (CAR) has a significant positive effect on ROA indicating that the higher the CAR, the greater the ROA obtained by the bank. According to (Dendawijaya, 2003), CAR is an indicator of a bank's ability to cover a decrease in its assets as a result of bank losses caused by risky assets. These risky assets tend to limit the amount of capital available in profit-generating activities. The higher the CAR, the stronger the bank's ability to bear these risky earning assets, to make profitability increase. The results of this hypothesis are in line with the research conducted by (Menicucci and Paolucci, 2016), (Vernanda and Widyarti, 2016) which states that CAR has a significant positive effect on ROA.

\section{Hypothesis Testing 4}

Based on the results of the regression analysis in table 6 above, the coefficient of influence of Capital $(\mathrm{X})$ on the bank performance $(\mathrm{Y})$ is 0.065 with a p-value of $0.00>$ alpha 0.05 . This shows that Capital has a positive and significant influence on performance. Thus the $\mathrm{H} 4$ Hypothesis which states that Capital has a positive and significant influence on bank performance is accepted. Bank size has a positive and significant effect on ROA, this indicates that increasing Size has a significant effect on increasing ROA. Banks that have large total assets influence gaining profits by managing good productive assets that can reduce nonperforming loans. This result is in line with the results of previous studies conducted by (Menicucci and Paolucci, 2016) which states that Size has a positive and significant effect on ROA.

\section{Conclusions}

Based on the results of the research and discussion by the objectives of the study, the following points will be concluded:

1. Herfindahl-Hirschman Index proved to have a negative and significant influence on bank performance. The higher the Herfindahl-Hirschman Index shows the market structure that leads to a monopoly structure so that in general it will have an impact on decreasing bank performance.

2. Lerner Index proven to have a positive and significant impact on the bank's performance case shows that when the monopoly power of banks individually increase will have an impact on the improvement of the control of resources and as well as assets owned by the bank, will have an impact on improving bank performance

3. Bank size proved to have a positive influence on ROA. With large assets that are dominated by productive assets and managed well, they will also generate large profits, thereby increasing bank performance.

4. Capital proved to have a positive and significant influence on bank performance. The higher the capital, the stronger the bank's ability to bear risky earning assets, so that it can increase bank performance.

\section{References}

1. Adelopo, I., Lloydking, R., \& Tauringana, V. (2018). Determinants of bank profitability before, during, and after the financial crisis. International Journal of Managerial Finance, 14(4), 378-398. https://doi.org/10.1108/IJMF-07-2017-0148

2. Ambarawati, I. G. A. D., \& Abundanti, N. (2018). Pengaruh Capital Adequacy Ratio, Non Performing Loan, Loan to Deposit Ratio Terhadap Return On Asset. E-Jurnal Manajemen Unud, Vol. 7(5), 2410-2441.

3. Bank Indonesia. (2019). Statistik Sistem Keuangan Indonesia SSKI.

4. Barney, J., Wright, M., \& Ketchen, D. J. (2001). The resource-based view of the firm: Ten years after 1991. Journal of Management, 27(6), 625-641. https://doi.org/10.1016/S0149-2063(01)00114-3 
5. Claessens, S., \& Leaven, L. (2003). What Drives Bank Competition? The World Bank: Financial Sector Operations and Policy Department, (August).

6. Dendawijaya, L. (2003). Manajemen Perbankan (Edisi Kedu). Jakarta: PT. Galia Indonesia.

7. Djalilov, K., \& Piesse, J. (2016). Determinants of bank profitability in transition countries: What matters most? Research in International Business and Finance, 38, 69-82. https://doi.org/10.1016/j.ribaf.2016.03.015

8. Hafidz, J., \& Astuti, R. I. (2013). Tingkat persaingan dan efisiensi intermediasi perbankan indonesia.

9. Hawtrey, K., \& Liang, H. (2008). North American Journal of Economics and Finance Bank interest margins in OECD countries. North American Journal of Economics and Finance, 19, 249-260.

10.Jumono, S., Achsani, N. A., Hakim, D., \& Firdaus, M. (2016). Industri Perbankan Indonesia Periode 2001-2014: Deteksi Konsentrasi Pasar Dan Prestasi ALMA. Jurnal Ekonomi, 7, 42-54.

11.Kosmidou, K., \& Zopounidis, C. (2008). Measurement of Bank Performance in Greece. SouthEastern Europe Journal of Economics C. ZOPOUNIDIS South-Eastern Europe Journal of Economics, 1(1), 7995.

12.Kv, B. M., \& Deb, A. T. (2008). Theoretical Framework Of Competition As Applied To Banking Industry. MPRA Paper http://mpra.ub.uni-muenchen.de/7465/.

13.Martins, A. M., Serra, A. P., \& Stevenson, S. (2019). Determinants of real estate bank profitability. Research in International Business and Finance, 49, 282-300. https://doi.org/10.1016/j.ribaf.2019.04.004

14.Menicucci, E., \& Paolucci, G. (2016). The determinants of bank profitability : empirical evidence from European banking sector. Journal of Financial Reporting and Accounting, Vol. 14(No. 1), pp 86-115.

15.Muazaroh, Eduardus, T., Husnan, S., \& Hanafi, M. M. (2012). Determinants of Bank Profit Efficiency: Evidence from Indonesia. International Journal of Economics and Finance Studies, 4(2), 164-173.

16.Mulyaningsih, T., \& Daly, A. (2012). Competitive Conditions in Banking Industry: an Empirical Analysis of the Consolidation, Competition and Concentration in the Indonesia Banking Industry Between 2001 and 2009. Buletin Ekonomi Moneter Dan Perbankan, 14(2), 151-186. https://doi.org/10.21098/bemp.v14i2.461

17.Naylah, M. (2010). Pengaruh Struktur Pasar Terhadap Kinerja Industri Perbankan Indonesia. MM Undip TESIS.

18.Rofiatun, N. F. (2016). Analisis Pengaruh Pangsa Pasar dan Indikator Perbankan terhadap Profitabilitas Bank Umum Syariah (Studi Kasus : pada Bank Umum Syariah Di Indonesia). JIE Lariba, 2(2), 115.

19. Keuangan, O. J. (2018). Statistik Perbankan Indonesia SPI.

20.Petria, N., Capraru, B., \& Ihnatov, I. (2015). Determinants of Banks' Profitability: Evidence from EU 27 Banking Systems. Procedia Economics and Finance, 20(15), 518-524. https://doi.org/10.1016/s22125671(15)00104-5

21.Priem, R., \& Butler, J. (2001). Is the RBV a Useful Perspective for Strategic Management Research? Academy of Management Review, 26(1), 22-40. https://doi.org/10.5465/AMR.2001.4011938

22.Salvatore, D. (2006). Microekonomics (4th ed.). Mc Graw-Hill International Edition.

23.Shaffer, S. (2014). Structure, Conduct, Performance, and Welfare. Review of Industrial Organization, 9(4), 435-450.

24.Soelistianingsih, L., \& Oktaviani, D. (2013). Pengaruh Kepemilikan Asing terhadap Tingkat Persaingan Industri Perbankan Indonesia: Pendekatan Panzar-Rosse.

25.Suhel. (2015). Analisis Struktur dan Kinerja: Studi Pada Industri Perbankan Syariah di Indonesia. Ekonomi Pembangunan, 13 no. 1, 1-9.

26.Tan, Y. (2016). The impacts of risk and competition on bank profitability in China. Journal of International Financial Markets, Institutions and Money, 40, 85-110. https://doi.org/10.1016/j.intfin.2015.09.003

27.Tran, V. T., Lin, C. T., \& Nguyen, H. (2016). Liquidity creation, regulatory capital, and bank profitability. International Review of Financial Analysis, 48, 98-109. https://doi.org/10.1016/j.irfa.2016.09.010 
28.Vernanda, S. D., \& Widyarti, E. T. (2016). ANALISIS PENGARUH CAR, LDR, NPL, BOPO, DAN SIZE TERHADAP ROA (Studi pada Bank Umum Konvensional yang Terdaftar di Bursa Efek Indonesia Periode 2010-2015). DIPONEGORO JOURNAL OF MANAGEMENT, Vol 5, 1-13. Retrieved from http://ejournals1.undip.ac.id/index.php/dbr

29.Yeyati, E. L., \& Micco, A. (2007). Concentration and foreign penetration in Latin American banking sectors: Impact on competition and risk. Journal of Banking and Finance, 31(6), 1633-1647. https://doi.org/10.1016/j.jbankfin.2006.11.003

30.Yusniar, M. W. (2011). Analisis Efisiensi Industri Perbankan di Indonesia Dengan Pendekatan Data En- velopment Analysis ( Dea ) Dan Faktor .. Faktor Yang Mempengaruhinya. Jurnal Manajemen \& Bisnis, 1(2), 175-195. 